\title{
Meet the 2021 Ralph Bunche Summer Institute Scholars
}

\author{
JASMINE SCOTT | AMERICAN POLITICAL SCIENCE ASSOCIATION
}

T

he APSA Ralph Bunche Summer Institute (RBSI) is an annual five-week program, held at Duke University, under the direction of Dr. Paula D. McClain. RBSI is designed to introduce undergraduate students from underrepresented racial and ethnic groups to the world of graduate study and to encourage application to political science PhD programs. This is the 35 th year of the program. The 2021 institute was held May 23-June 23, 2021. Please join us in congratulating the 2021 scholars!

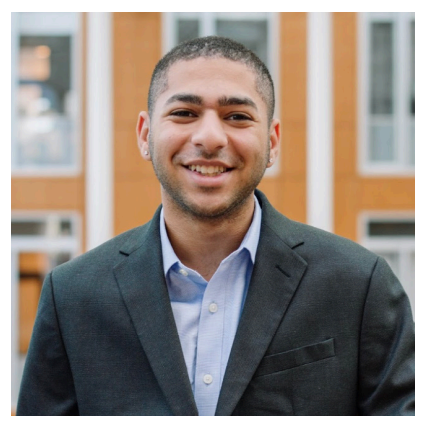

Youssef Aziz is a junior at Cornell University studying sociology and psychology and minoring in inequality studies on a health equity track. He is currently a research assistant at the Social Perception and Intergroup Inequality Lab conducting a project that examines how negative out-group stereotypes can affect one's mental representations of the outgroup's facial features. He is also a current Arabic-speaking Research and Investigations intern at Physicians for Human Rights (PHR) where he researches human rights violations in Syria and Egypt. At Cornell, Youssef is a Meinig Scholar (top $2 \%$ of student leaders) as he is heavily involved with the first-generation, low-income community, and anti-racist initiatives on campus. Youssef immigrated from Egypt at the age of 12 after the Egyptian Revolution due to political instability and religious persecution. Because of his personal experience with systemic violence across both hemispheres, he developed an interest in how cultural identities form and morph throughout different political systems within indigenous North African populations. Indigenous North African issues are actively erased within academia due to broad, westernized generalizations about "MENA." Youssef aims to shed light on how indigenous populations have reconciled with their heavily colonized identities by examining how current oppressive political systems have influenced their views on Blackness and pan-Africanism. Passionate about international human rights law and making space for his communities within academia, Youssef aims to pursue a $\mathrm{JD} / \mathrm{PhD}$ after graduation.

Christian Caballero is a rising senior studying politics and sociology at New York University. Christian's main research

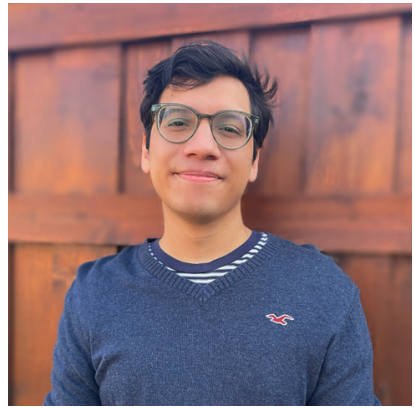

interests involve the study of social media, misinformation, and the effects they have on behavior and opinion. He has been able to pursue this interest as a research assistant at NYU's Center for Social Media and Politics where he has assisted on projects that pertain to the spread of fake news and misinformation. He has also assisted at The Center for Radical Innovation for Social Change (RISC) at The University of Chicago, where he has been able to promote the use of social media as a tool for effective and civil discourse through collaborations with prominent social media platforms such as Twitter. As a Chicano first-generation, low-income student, Christian is proud to participate in the RBSI and contribute to its mission of promoting underrepresented scholars and scholarship. After graduation, Christian hopes to pursue a $\mathrm{PhD}$ in political science with a concentration in political behavior and social media.

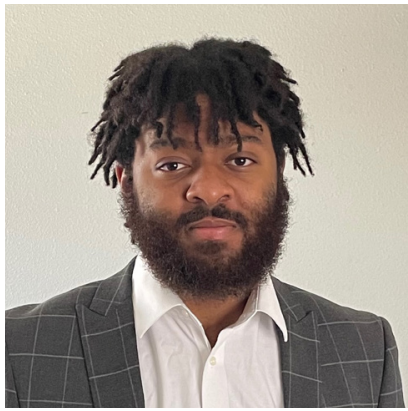

Darius Cozart is a junior honors student, studying political science with a minor in history at The George Washington University. He is the recipient of multiple scholarships, including the International Baccalaureate Scholarship, the Sachs Foundation Scholarship, and the Delta Eta Boule Scholarship. Darius has made the Dean's List in each of his previous five semesters while remaining engaged in campus and community organizing. He was an administrator of the student-run BIPOC Collective, fighting for curricular and program changes to make the University Honors Program more inclusive. Additionally, Darius has worked as an intern in the DC offices of both Representative Diana DeGette and Representative Pramila Jayapal, chair of the Congressional Progressive Caucus. His research interests include inequality in the American political system, the politics of incarceration, and the distortive and harmful aspects of American foreign policy. Upon graduation, Darius plans to pursue a PhD in political science. 


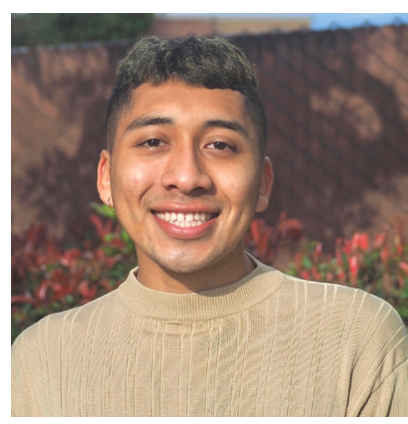

Diego Flores is a first-generation, rising senior at Pitzer College majoring in political science and Latin American studies from East Los Angeles. As a Highlander Institute Fellow, Braun Fellow for Youth Activism, and co-president of the labor justice club and Claremont Student \& Worker Alliance, Diego has demonstrated his commitment to academia and social change. Diego's research interests include Latin American political economy and immigration, globalization and neoliberal policy, and the Latin American Drug War's connection to migration and neoliberalism. He is particularly interested in the intersection of academia and justice movements domestically and abroad. As a research assistant with Professor Melissa Rogers, he is researching the political determinants of contemporary Latin American urbanization and the influence of the city and countryside in this process. Upon graduating, he hopes to secure a fellowship in Latin America and pursue graduate studies in political science or Latin American studies.

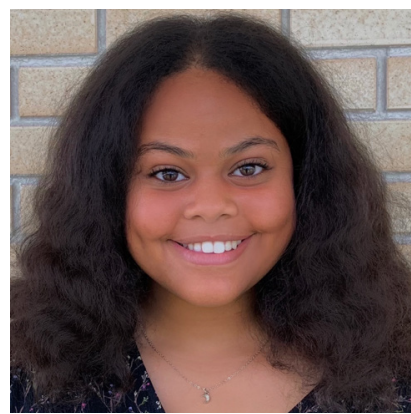

Monica Gebrehiwot is a rising senior at the University of Houston majoring in political science with a double minor in quantitative social science and religious studies. She is a member of Pi Sigma Alpha, the political science honor society. Monica has attended Texas A\&M's data workshop where she worked on her proficiency in STATA. She has participated as a research fellow for the University of Houston's Summer Undergraduate Research Fellowship (SURF) to expand on Richard N. Engstrom and Richard L. Engstrom's research by collecting and analyzing data on primary runoff elections. She has also worked as a research assistant in a Machine-Assisted Human Decision-making (MAHD) lab where she moderated discussions in important matters of public policy, such as healthcare reform. Monica's research interests encompass American politics with an emphasis in behavior and psychology as well as comparative politics.

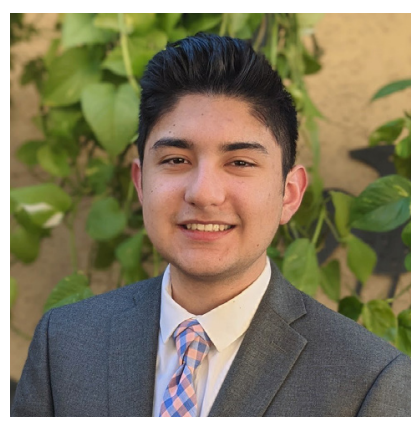

Nicolas Hernandez is a rising fourth-year student at California State Polytechnic University, Pomona majoring in political science and communication with an emphasis in multimedia journalism. Born in Bogota, Colombia and immigrating to the United States at the age of 5 , he has long valued the opportunities presented by the pursuit of further education. At Cal Poly Pomona, he has participated in research examining mass media framing of underrepresented political candidates and the undocumented student experience.
He has also served in informing the Cal Poly Pomona community as a staff writer and copy editor for The Poly Post newspaper. Outside of campus, he was a summer 2020 participant in the Congressional Hispanic Caucus Institute program and interned with the Phil Arballo for Congress campaign. Upon graduation, he plans to pursue a $\mathrm{PhD}$ in political science with a focus on American political institutions.

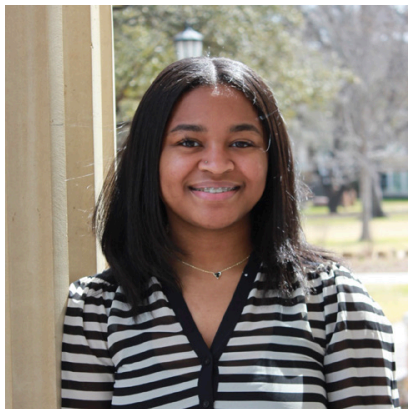

Janae Jackson is a third-year honors student at Texas Christian University, double majoring in political science and sociology and minoring in comparative race and ethnic studies. Her hometown of Fort Worth, Texas, informs her personal and professional interests in social justice. At TCU, she is a Community Scholar, an Annexstad Leaders for Tomorrow Scholar, a Ronald E. McNair Scholar, and a fivetime Dean's List recipient. She has conducted independent research on international policing practices as part of a political science summer research program. Her research interests include the carceral state, radical political theory, and social policy. In particular, her personal experiences with punitive school policies in the public education system led to her commitment to carceral abolition. Jackson currently interns at the Mothers Outreach Network in Washington, DC where she collects data on universal basic income to be used in upcoming grant proposals to fund small-scale financial security pilot programs for African American mothers in the city. After graduation, Jackson will pursue a $\mathrm{PhD}$ in political science with a concentration in the criminal legal system at the intersection of race and gender.

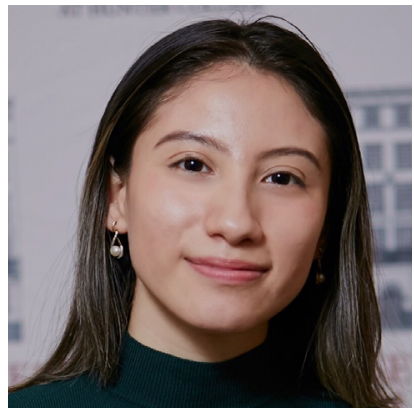

Montserrat Lopez is a thirdyear Roosevelt Scholar at Hunter College, majoring in political science with minors in public policy and economics. Born in Mexico, she moved to Queens, New York, at five years old and is now a DACA recipient. Montserrat has experience as an intern in the private and nonprofit sector at Calcaterra Pollack LLP and UnLocal. She has served as a Senior Health Educator for Peer Health Exchange, a community organizer for El Puente in Williamsburg, and continues to advocate for marginalized communities. After graduation, Montserrat plans to pursue a joint $\mathrm{PhD} / \mathrm{JD}$ to further her drive for public interest and public policy. She plans to study labor law and migration to bring a nuanced and personal view to economic policy that protects immigrants.

Shanequewa Love is a first-generation, non-traditional, rising senior majoring in African American studies at Loyola Marymount University. She is a Ronald E. McNair Scholar, an Ebell of Los Angeles Scholarship recipient, a recipient of the Dean's List, and a Student Ambassador at Loyola Marymount University. As a Ronald E. McNair Scholar, she is currently conducting research with Dr. Magaela Bethune on the exposure to sexual 


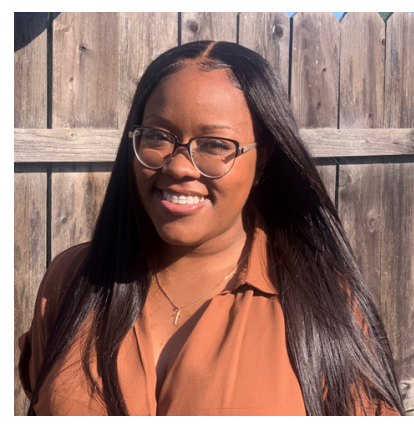

trauma in adolescence and its relationship to sexual outcomes in young women. She has previously conducted research on the educational structure within the foster care system with Dr. Louvenis Jackson, research on youth vaping in the United States, and policies restricting access to new tobacco products in academic institutions with Dr. Roberto Cancio. Shanequewa's research interests also include race, ethnicity, and politics, disparities in the educational system, and the systemic barriers faced by foster youth. After graduation, she intends to pursue a $\mathrm{PhD}$ in human development, social policy, or public policy. She is dedicated to her community and is passionate about advocating for individuals whose voices remain silent in society.

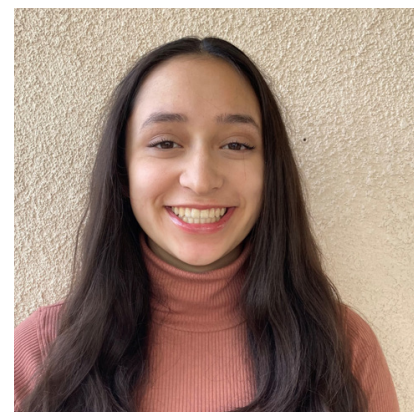

Rossandra Martinez is a third-year, transfer student at University of California, Riverside, majoring in political science and history. She is passionate about race and gender politics and immigration issues. During her time at Imperial Valley College, she was president of Students for Political Action and Awareness. Through this organization she organized voter registration drives, county candidate forums, and collaborated with social justice groups such as Border Angels, Migrant Child Watch, Imperial Valley Social Justice Committee, Black Lives Matter, and the American Civil Liberties Union. This spring, Rossandra hopes to further her research in the area of farming labor conditions through examining the potential social effects of digital and robotic technology on California agricultural laborers.

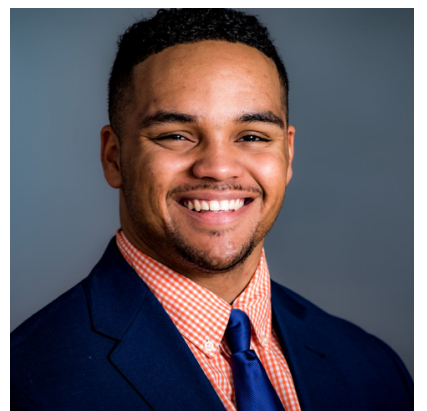

Ty Mills is a rising senior at Randolph-Macon College majoring in political science with a double minor in Asian studies and economics. On campus he is a tour guide and loves interacting with prospective students. He is also a member of the football team and has been a student athlete for three years. Off the field he is a recipient of the Porter Hardy, Jr. scholarship which recognizes outstanding political science students at Randolph-Macon College. He is a five-time dean's list recipient and three-time All-Academic Old Dominion Athletic Conference member. He was awarded the T. McNider Simpson Scholarship for his leadership and engagement on campus. He enjoys volunteering at the local elementary school as a mentor for youth in the community. Ty is passionate about introducing financial literacy to minority communities so that they can improve their living conditions. After graduation, Ty wants to attend graduate school to work toward improving the lack of financial literacy in the minority communities.

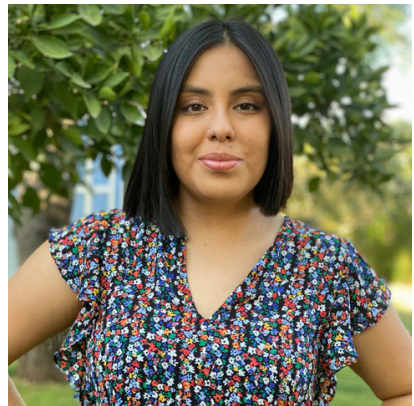

Carolina Olea Lezama is a first-generation student from Phoenix, Arizona. She is a rising senior at Tufts University double majoring in political science and American studies and has maintained Dean's List for the past four semesters. At Tufts, Carolina has worked on researching the relationship that Tufts' host communities of Medford and Somerville have with their police departments. She is also a member of the TCU Senate where she is an advocate for marginalized communities. She is passionate about mobilizing and uplifting the Latinx community and has spent time interning with the Hispanic Federation in New York City, the Massachusetts's Voter Table, and Representative Grijalva's office (AZ-03). She also spent this past summer working with the Center for Information and Research on Civic Learning and Engagement at Tufts and was a member of the Congressional Hispanic Caucus Institutes' (CHCl) 2020 Summer internship cohort. Carolina's research interests include race and identity politics and how they impact political behavior. She hopes to uplift the voices of the Latinx community in the research field.

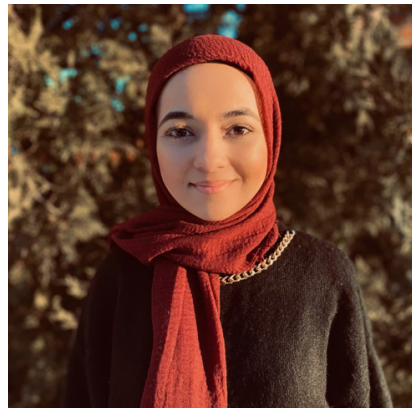

Medina Talebi is a third-year honors student at Drexel University majoring in political science with a minor in war and society. As an undergraduate researcher for the Project on Shi'ism and Global Affairs at Harvard University's Weatherhead Center for International Affairs, she has focused on religiously-affiliated transnational communities in the Persian Gulf. Her primary research project, for which she has been awarded a grant, is entitled "Mapping the Narrative of Shi'a Genocide," which explores the development of genocide narratives espoused by both indigenous activists and stakeholders within the Shi'a diaspora. Medina presented her research at the National Collegiate Research Conference at Harvard University, was accepted to present at the Stanford Research Conference, and was a semi-finalist at the Yale International Policy Competition. Currently, she serves as a student representative for her college's Committee for Diversity, Equity, and Inclusion. Recently, she joined the Union of Concerned Scientists as a consultant for an international democracy reform project. Additionally, she serves as the Outreach and Communications Chair for Biddle Law Society at Drexel. In the future, Medina aims to draw more attention both academically and professionally to the effect of political violence on marginalized communities.

Amilcar Torres is a rising senior at the University of Cincinnati majoring in political science, international relations, and Spanish. He is a part of the Darwin T. Turner Scholars and University Honors Programs. Amilcar also serves as the Head Delegate and is on the executive board for his school's competitive Mod- 


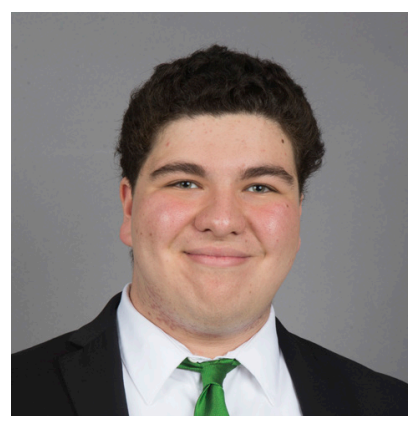

el United Nations travel team. Within the department of political science, he was recently invited to join the Inclusive Excellence Council, a joint committee of a small group of senior undergraduate students who meet several times a semester with a wide variety of professors in the department to work on initiatives and discuss ways to become more inclusive and better help students who choose to study political science. He has spent the past two summers as a research assistant for professors within the political science and history departments at his university. After graduation, Amilcar plans to pursue a doctoral degree in international relations.

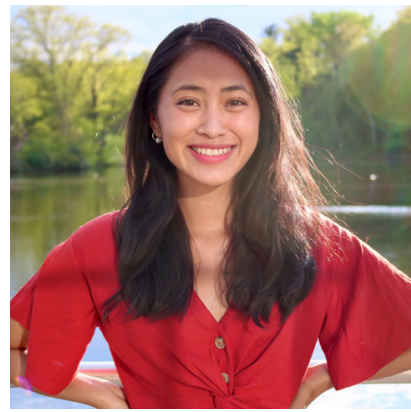

Yamilet Velez is a rising senior at Smith College majoring in government with a concentration in comparative politics. Velez is a first generation and low-income college student from Los Angeles, CA. Velez is proud of her Mexica Nahua identity and is passionate about working towards a progressive immigration reform plan in the US and indigenous autonomy across Latin America. As a UCLA DREAM Fellow this past summer, she worked with the Garment
Worker Center (GWC), where she conducted ethical brand research to help detect and prevent violations of OSHEA'S COVID-19 regulations at the workplace in order to foster a safe working environment for garment workers across LA County. She has also interned with the Coalition for Humane Immigrant Rights (CHIRLA) where she canvassed for Measure EE to help bring more resources to underfunded schools across LA County. As a CHIRLA intern, she also participated in lobby visits to Capitol Hill in early 2018 where she urged Congress members to support a Clean Dream Act, to provide a clean path towards citizenship for many undocumented immigrants and demilitarize the US-Mexico border and immigrant communities across the US. Post-graduation, she hopes to pursue a joint degree in constitutional law and political science.

Applications for the 2022 institute will open in October 2021. Learn more about RBSI at https://www.apsanet.org/rbsi

\section{NEW: Join an APSA Related Group}

APSA Related Groups are professional groups, engaged in the study of political science. Related Groups add diversity and represent a broad spectrum of civic and political issues. Groups also host panels, workshops, and receptions at the APSA Annual Meeting.

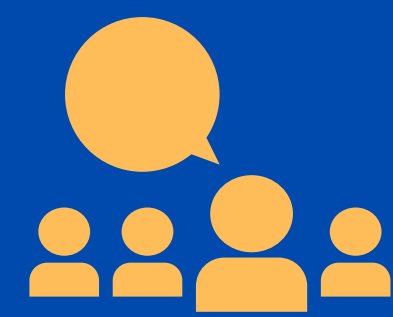

www.apsanet.org/RESOURCES/Related-Groups

\section{Related Groups include:}

- subject matter groups

- caucuses

- identity groups

- think tanks

- nonprofits

- other academic

associations
45 Related

Groups and no

additional fees

to join!
Login to your account at

apsanet.org, click your

name at the top of the page

and select Related Groups

on the right hand side to

add a group. 